\title{
Tüketicilerin Mobil Uygulamalara İlişkin Algılarının Teknoloji Kabul Modeli İle Değerlendirilmesi (Evaluation of Consumers' Perceptions About Mobile Applications According to The Technology Acceptance Model)
}

\begin{abstract}
Ahmet UYAR
a Afyon Kocatepe Üniversitesi, Bolvadin Uygulamalı Bilimler Yüksekokulu, Afyonkarahisar, Türkiye. ahmetuyar@aku.edu.tr
\end{abstract}

\begin{tabular}{ll}
\hline MAKALE BİLGisi & ÖZET \\
\hline Anahtar Kelimeler: & Amaç - Küreselleşme ile birlikte teknolojik gelişmeler dünya geneline yayılmakta ve bu \\
Teknoloji Kabul Modeli & yenilikler farklı tüketici grupları tarafından kullanılmaya başlanmaktadır. Hızla gelişen ve \\
Mobil Uygulamalar & farklılaşan uygulamalar insanların teknolojiye adaptasyonu sorununu gündeme getirmektedir. \\
Yapısal Eşitlik Modeli & Konuyla ilgili literatürde çeşitli modeller geliştirilmektedir. Çalışmanın amacı Teknoloji Kabul \\
& Modeli çerçevesinde tüketicilerin mobil uygulamalara adaptasyonunun belirlenmesi ve
\end{tabular}

Gönderme Tarihi 10 Ocak 2018

Revizyon Tarihi 22 Mart 2019

Kabul Tarihi 25 Mart 2019

Makale Kategorisi:

Araştırma Makalesi
Yöntem - Bu amaç doğrultusunda teknoloji kabul modeli açıklanmış, konuyla ilgili tüketiciler üzerine 17 soruluk 5'li likert tipi bir anket uygulanmıştır. Araştırmaya 320 tüketici katılmıştır. Anket yöntemiyle toplanan veriler LISREL ve SPSS 18 programlarıyla analize tabi tutulmuş, yapısal eşitlik modeli yardımıyla açıklanmıştır. Çalışmada gizil değişkenler ve gizil değişkenlere ait gözlenen değişkenler arasındaki ilişkiler path diyagramı yardımıyla gösterilmiş, yapı güvenilirliği ve uyum ölçütleri verilmiştir. Ayrıca katılımcıların konuya ilişkin görüşleri ile demografik özelliklerinin karşılaştırılmasında ilişkisiz ölçümler için "t-testi" ve "Varyans (ANOVA) Analizinden" yararlanılmıştır.

Bulgular - Araştırma sonucunda elde edilen veriler göre kullanım kolaylığıyla ile kullanım niyeti arasında önemli bir ilişki bulunmuş, eğlence ve mobil hizmetlerden edinilecek yararın da kullanım niyetini açıkladığı görülmüştür.

Tartışma - Böylece tüketicilerin yeni gelişen uygulamalara adaptasyonunun sağlanması için kullanım kolaylığı, eğlence gibi faktörlerin önemi anlaşılmış ve sektör paydaşlarına konular hakkında bazı tavsiyelerde bulunulmuştur.

\begin{tabular}{l} 
ARTICLE INFO \\
\hline Keywords: \\
Technology Acceptance Model \\
Mobile Applications \\
Structural Equation Model
\end{tabular}

Received 10 January 2018

Revised 22 March 2019

Accepted 25 March 2019

Article Classification:

Research Article influence technology acceptance within the frame of the technology acceptance model. were observed to relate to latent variables were shown with the help of a path diagram, and

\section{ABSTRACT}

Purpose - Along with globalisation, technological developments spread around the world, and these novelties begin to be used by different consumer groups. Rapidly developing and differentiating applications bring forward the question of people's adaptation to technology. Various models are being developed in the literature relating to this subject matter. The purpose of the study is to determine consumers' adaptation to mobile applications, and the factors which

Design/methodology/approach - For this purpose, the technology acceptance model was explained, and a 5-point Likert-type questionnaire comprising 17 questions was administered to consumers. A total of 320 consumers participated in the research. The data collected with the questionnaire method was analysed with the LISREL and SPSS 18 software, and explained with the help of the structural equation model. In the study, latent variables and those variables that construct reliability and fit criteria were given. Also, the "t-test" and "Variance ANOVA Analysis" were utilised for unrelated measurements in the comparison of the participants' opinions about the subject matter and their demographic characteristics.

Findings - The data obtained as a result of the research showed a significant relationship between ease of use and intention of use, and it was seen that the benefit to be obtained from entertainment and mobile services also explain the intention of use.

Discussion - In this way, factors considered to be important for ensuring consumers' adaptation to newly developing applications were determined and some recommendations were offered to sector stakeholders about certain issues. 


\section{GİRIŞ}

Mobil iletişimin gelişmesi mobil tabanlı uygulamalarda büyük bir artışa neden olmuştur. Ağların, cihazların ve telekomünikasyonun yaygınlaşması tüketicilerin bu teknolojilere kolay ulaşmasını sağlamaktadır (Bamba ve Barnes, 2007). Mobil telefonlar kişisel cihazların kullanımını arttırmış firmalar açısından tüketicilerle iletişim kuma imkanları genişlemiştir (Scharl vd., 2005). Mobil iletişimde yaşanan bu büyük değişim süreci müşterilerle işletme arasında çok farklı platformların ortaya çıkmasına neden olmuştur (Bauer vd., 2005; Shankar ve Malthouse, 2007; Sultan ve Rohm, 2005). Günümüz tüketicileri açısından mobil cihazlar gündelik hayatın vazgeçilmez bir parçası haline gelmiştir (Gong ve Li, 2008; Sultan vd., 2009). Konuyla ilgili yapılan çalışmalarda tüketicilerin mobil faaliyetleri kişiselleştirmesi, herhangi bir mekân sınırlaması olmadan servislere ulaşmaları ve zaman/maliyet avantajı sağlaması gibi nedenlerle mobil teknolojileri kullandıkları görülmüştür. Bunun yanında batarya ömrünün kısa olması, kişisel verilerin korunamaması, hız, kapsama sorunları gibi nedenler ise mobil hizmetlerin olumsuz taraflarını oluşturmaktadır (Pagani, 2004).

Türkiye'de akıllı telefon kullanım oranı \%84 civarındadır. Tüketicilerin \%2'si yılda bir kez telefonunu değiştirmektedir. Ortalama değişim süresi 3,2 senedir. Çağımızın hastalığı olarak görülen Nomofobi yani cep telefonu ile kurulan iletişimden uzaklaşma korkusu giderek büyümektedir. Avrupa'da insanlar günlük olarak ortalama 48 kez cep telefonunu kontrol etmekteyken bu rakam ülkemizde 78'e yükselmiştir. Ayrıca Türkiye'de tüketiciler telefonlarına hazır yüklü olarak gelen uygulamalar hariç 17 mobil uygulama daha telefonlarına yüklerken Avrupa'da bu sayı 24'dür (http://www.haberturk.com/). Ülkemizdeki tüketicilerin \% 70'i mobil uygulamaları kısa videolar izlemek için, \%59'u haber okumak, \% 53'ü sosyal medyaya resim yüklemek, \% 36'sı ise müzik dinlemek için kullanmaktadır (https://webrazzi.com). Mobil uygulamaların kullanımı arttıkça daha önce tüketiciler tarafından hiç deneyimlenmemiş, yeni teknolojiler ve uygulama biçimleri hayatımıza girmektedir. Mobil uygulamaların sürekli değişmesi ve yeni yöntemlerin geliştirilmesi tüketicilerin teknolojiye adaptasyonunu zorlaştırmaktadır. $\mathrm{Bu}$ nedenle tüketicilerin teknolojiye adaptasyonunu inceleyen çalışmalar yapılmakta, modeller geliştirilmektedir. İnsanların hangi konularda zorlandıklarını anlamak ve buna uygun çözüm yolları bulmak için teknoloji kabul çalışmalarının yapılmasinda fayda vardır (Wu vd., 2004; Lu, 2009).

$\mathrm{Bu}$ çalışmada mobil uygulamaları kullanma niyetine etki eden faktörlerin belirlenmesi amaçlanmaktadır. Böylece insanları mobil uygulamalara adapte eden ve kullanılmasını sağlayan faktörler saptanarak, tüketicileri mobil uygulamalardan uzaklaştıran nedenlerin belirlenmesi ve ona uygun çözüm önerileri getirilmesi amaçlanmaktadır. Çalışmada Nyrhinen ve Leskinen (2014) tarafından geliştirilen model temel alınmıştır. Diğer modeller yerine bu modelin kullanılmasının nedeni tüketicilerin mobil uygulamaları kullanım niyetini eğlenme, kullanım kolaylığı, fayda gibi oldukça geçerli değişkenlerin etkisiyle ölçmesidir.

Çalışmanın temel amacı tüketicilerin mobil uygulamalar konusunda yaklaşımlarını Teknoloji Kabul Modeli çerçevesinde incelemektir. Böylece her geçen gün hayatımıza daha fazla girmeye başlayan mobil uygulamalara insanların yaklaşımları araştırılmış, gelecekte bu tür uygulamalara karşı nasıl davranacakları anlaşılmaya çalışılmıştır. Çalışmanın alt amaçları ise; teknolojiye uyum çerçevesinde tüketici davranışlarını tahmin etmek, tüketicilerin mobil uygulamalara adapte olmak için hangi faktörlerin etkili olduğunu saptamaktır. Çalışmada "algılanan fayda", "algılanan kullanım kolaylığı", "eğlenme" gibi faktörlerin kullanım niyeti üzerindeki etkisi araştırılmıştır.

Literatür taraması sonucunda Planlı Davranış Teorisi, Sebepli Davranış Teorisi incelenmiş ve bunun sonucunda Teknoloji Kabul Modelinin en uygun model olduğu düşünülmüştür. Araştırma sonunda mobil uygulama üretmek isteyen firma ve kişilere elde edilen veriler ışığında bazı tavsiyelerde bulunulmuştur.

\section{KAVRAMSAL ÇERÇEVE}

\subsection{Mobil Uygulamalar ve Tüketici Etkileşimi}

Mobil kelimesi Fransızca kökenli olup hareket halinde olma, taşınabilme anlamına gelmektedir. Başka bir deyişle kablosuz taşınabilme özelliğini anlatmaktadır (www.tdk.gov.tr). Türkçeye "uygulama" olarak geçen "application-app" kelimesi 2010 yılında ortaya çıkmış, Amerikan Diyalekt Topluluğunca yılın kelimeleri arasında gösterilmiştir (www.americandialect.org). 
Mobil uygulamalar tablet, cep telefonu gibi taşınabilir cihazlar için geliştirilmiş olan uygulamalara verilen isimdir. Mobil uygulamalar gelişim aşamaları açısından masaüstü uygulamalarla aynı süreçlerden geçse de kullanım biçimleri, teknolojileri, içerikleri açısından bazı farklılıklar barındırmaktadır (Namlı, 2010). Mobil uygulamalar hızla gelişen bir ortam içerisinde ele alınmalıdır. Taşınabilir cihazlarla kullanılabilmelerinden ve yaygın bir tüketici kitlesine hitap etmelerinden dolayı daha yenilikçi ve farklı özellikler taşımaktadır.

Mobil uygulamaların yaygınlaşmasının nedeni insanların sabit bir bilgisayara bağlı kalmadan yapmaları gereken işleri zamanında ve hızlı bir şekilde yapabilmelerine olanak tanımasıdır. Bu durum tüketicilere hareket özgürlüğü tanımaktadır. Birçok firma bu avantajlarından dolayı çok çeşitli mobil uygulamalar tasarlamakta ya da var olan uygulamalarını güncellemektedir (Beyaznar, 2014).

Apple 2008 yılında ilk Apps Store yani uygulama mağazasını kurmuştur. Yine ekim 2008 yılında Android Market kurulmuştur. Android işletim sistemine sahip telefonlar için tasarlanan bu mağaza 2012 yılından bu yana Google Play olarak hizmet vermeye devam etmektedir (Rosenberg, 2012). Tüketiciler tarafından kullanılan uygulamaların önemli bir bölümü bu iki perakende mağaza tarafından karşılanmaktadır.

İlk başlarda insanlara bilgi sağlayan hava durumu, piyasa bilgileri, takvim, döviz, e-mail gibi özellikler şeklinde ortaya çıkan uygulamalar zamanla yaygınlaşarak farklı alanları kapsamaya başlamıştır. Son yıllarda müşteri ilişkilerinde, bankacılık hizmetlerinde, oyunlarda, sosyal medyada mobil uygulamalara sıkça rastlanmaya başlanmıştır (Mobilsiad Milli Uygulama Pazarı Raporu, 2013).

Mobil telefonlar ilk ortaya çıktığında tüketicilere sabit bir yerde olmadan iletişim imkânı sağlamasından dolayı kişilerarası iletişimin farklı bir yöntemi olarak tanıtılmıştı. Zaman içerisinde altyapı ve teknolojideki ilerlemelerden dolayı işletmeler tarafından mobil pazarlama önem kazanmaya başlamış, multimedya hizmetlerinin de gelişmesiyle birlikte mobil sektörü karmaşık bir yapıya bürünmüştür (Varnalı vd., 2011).

Geniş bir kitleye hitap ettiğinden dolayı işletmeler mobil uygulamalara çok büyük önem vermeye başlamıştır. Günün her saati müşterileriyle iletişim kurabilme imkanı sağlayan mobil uygulamaların tüketicilere ve firmalara katkıları şöyledir (Ryan, 2016; Smutkumpt vd., 2010);

- Mobil uygulamalar müşteri ile işletme arasında interaktif bir iletişim ortamı sağlayarak yeni ürün ve hizmetlerin ortaya çıkmasına neden olur. Açı inovasyon sistemini geliştirir.

- Mobil uygulamalar sayesinde tüketicilerden edinilen bilgiler ürün çeşitlemesine ve genişletilmesine fayda sağlar.

- Mobil uygulamalar online topluluklar oluşturarak tüketici grupları oluşturmaya yarar.

- Müşteri sadakati konusunda geliştirilecek yöntem ve teknikler konusunda uygun bir ortam sağlar.

- İnsanların firmalar hakkında kendi aralarında görüş iletmesini sağlayarak viral pazarlamaya yol açar.

- Marka imajı arttırma, marka farkındalığı sağlama konularında işletmeye katkı sağlar.

- Tüketicilerin daha derin bir marka deneyimi yaşamalarını sağlar.

- Tüketicilerin işletmeye daha kolay ulaşmalarını sağlayarak müşteri firma arasındaki bağı güçlendirir. Şikâyet ve isteklerin daha hızlı bir şekilde iletilmesine neden olur.

- Pazarın yaş, cinsiyet, gelir ve konuma göre daha iyi bölümlendirilmesini sağlar.

- Doğrudan satışa imkân tanır.

- Reklam, halkla ilişkiler, promosyon gibi pazarlama yöntemlerinin kapasitesini arttırır ve yeni tekniklerin gelişmesine neden olur.

- Tüketicilerin fiyat konusunda bilgi edinmelerini kolaylaştırır.

\subsection{Teknoloji Kabul Modeli ve Teorik Arka Planı}

Bilgi teknolojileri son yıllarda yaygınlaşmakta, insanlara zaman ve maliyet açısından birçok avantajlar sunmaktadır. Bu nedenle tüketicilerin bilgi teknolojilerine yaklaşımlarını ve onu yeterli şekilde kullanıp kullanmadıklarını anlamak önemlidir (Turan ve Özgen, 2009). Konuyla ilgili yapılacak çalışmalar şu sorulara yanıt verecektir (Özer, Özcan ve Aktaş, 2010): 
- Tüketiciler yeni geliştirilen teknolojilere direnç gösterecek mi? Eğer bir uyumsuzluk varsa bunun sebepleri nelerdir?

- Tüketiciler yeni geliştirilmiş bir teknoloji varsa bunu kullanıp kabullenmelerinin koşulları nelerdir?

- Tüketiciler mevcut durumda kullandığı teknoloji ve uygulamaları gelecekte de kullanmaya devam edecekler midir?

Teknolojiye tüketicilerin adaptasyonunun nasıl olduğunu ortaya koymak için çeşitli teoriler geliştirilmiştir. Bunlardan en eski olanlarından biri sebepli davranış teorisidir. Sebepli Davranış Teorisi (SDT) (Theory of Reasoned Action - TRA) insanların tutum ve davranışları arasındaki bilinçli ilişkinin belirlenmesi amacıyla kullanılan bir yöntemdir (Ajzen ve Fishbein, 1980). Teoriye göre bir kişinin niyetini (BI) belirleyen faktörler tutum (A) ve normdur (SN). Sebepli Davranış Teorisi şöyle formüle edilir (Davis, 1989) : BI = A+SN

Şekil 1'de Sebepli Davranış Teorisi gösterilmektedir. Şekle göre kişinin inanç ve değerleri tutumu oluştururken, normatif inançları öznel normları belirlemektedir. Tutum ve normlar ise niyeti meydana getirmekte, niyet sonuç itibariyle gerçekleşen davranışa neden olmaktadır. Teoride yalnızca kişinin kendisinin gerçekleştirildiği ve kendi kontrolüyle yapılan davranışlar açıklanmaktadır (Erten, 2002). Ancak her zaman gelişen durumlar buna uygun olmayabileceğinden ve başka kişilerin yardımını gerektiren durumlar da olduğundan teori yetersiz kalmaktadır (Erdem, 2011).



Şekil 1. Sebepli Davranı̧ Teorisi (Kaynak: Davis vd., 1989: 984)

1991 yılında Sebepli Davranış Teorisinin eksikliklerini gidermek amacıyla Ajzen (1991) tarafından planlı davranış modeli oluşturulmuştur (Çam, 2012). Teoriye göre niyetin iki değil üç belirleyicisi bulunmaktadır. Algılanan davranışsal kontrol niyet üzerinde belirleyici bir unsur olarak modele eklenmiştir. Böylece kişilerin yalnızca tutumları ve toplumsal baskıyla oluşan düşünceleri değil davranışları da niyet üzerinde etki etmektedir. Örneğin bir yardım kuruluşuna destek olma isteğinde (tutum) bulunan bir kişi toplumu buna inandırmış olsa da (öznel norm) yeterli miktarda mali gücü yoksa (Algılanan Davranışsal Kontrol) bunu gerçekleştiremeyebilir (Turan, 2011). Beklenmedik bir zamanda ortaya çıkan ya da otomatikleşmiş, rasyonel olmayan davranışların varlığı Planlı Davranış Teorisine eleştirilerin doğmasına neden olmuştur (Kağıtçıbaşı, 2005). Şekil 2'de teori gösterilmektedir.



Şekil 2. Planlı Davranış Teorisi (Kaynak: Ajzen, 1991.) 
Sebepli Davranış Teorisi ve Planlı Davranış Teorisinden sonra geliştirilen diğer bir model Teknoloji Kabul Modelidir. Amacı insanların ve onun oluşturduğu toplulukların teknolojiyi nasıl algıladığını ortaya koymak ve bununla ilgili bir model oluşturmaktır. İnsan davranışına etki eden faktörlerin saptanarak teknoloji kullanımı açısından hangi değişkenlerin önemli olduğunu belirlemek, tüketicilerin teknolojik uygulamalar sonucunda elde ettikleri tatmin düzeyini ölçerek buna uygun sistemler geliştirmek iddiasında bulunmaktadır (Davis, vd., 1989).

Teknoloji Kabul Modelleri teknolojik uygulamaların kullanım kolaylığı, eğlenme, fayda gibi faktörlerin tüketicilerin teknolojiyi kullanma eğilimi ve davranışlarına olumlu katkı yaptığını göstermektedir. Çeşitli sektörler üzerine yapılmış birçok çalışma da bu varsayımı doğrulamıştır (Göğüş, 2014: 6). Bu nedenle yeni geliştirilen uygulamaların nasıl karşılanacağı ve tüketicilerin nasıl uyum göstereceklerini anlamak için Teknoloji Kabul Modeline ihtiyaç duyulmaktadır.

Teknoloji kabul modelleri bilişim sektöründe kullanıcıların eğilimlerini belirlemek için en çok başvurulan yöntemdir (Eriş vd, 2010). Modele göre yetersiz kullanıcı kabulü yeni uygulamaların ve teknolojilerin piyasaya çıkmasına engel teşkil etmekte, az sayıdaki ilişki ölçümüyle kuvvetli bir model elde edilmektedir (Lee vd, 2003). Ayrıca yapılan çalışmalardan elde edilen veriler tüketicilerin geliştirdiği tutumların teknoloji kullanma niyet ve istekliliğine yaklaşımlarını göstermektedir (Benbasat ve Barki, 2007).

Yeni bir teknoloji ve uygulama ortaya çıktığından insanların buna nasıl tepki vereceğini anlamaya çalışan tek sistem Teknoloji Kabul Modeli değildir. Başka modeller de bu konuya açıklık getirmeye çalışmaktadır. Teknoloji Kabul Modelinden daha eski olan ve onun yapı taşlarını oluşturan modellerden bazıları şunlardır;

Literatürde farklı sektörlerde Teknoloji Kabul Modeli ve ondan türetilen modellerle ilgili birçok çalışma yapılmıştır. Örneğin turistlerin internet kullanımı ve satın alma davranışları üzerine yapılan çalışmalar bulunmaktadır (Nunkoo ve Ramkissoon, 2013; Kim Chung ve Lee, 2011; Guritno ve Siringoringo, 2013). Guritno ve Siringoringo (2013) yolcuların havayolu taşımacılığında bilet satın alırken sergiledikleri davranışları incelemiş, güven, fayda ve kullanım kolaylığının bilet satın alırken tüketicilerin tutumu üzerine olumlu etki yaptığını bulmuşlardır. Nunkoo ve Ramkissoon (2013) turistlerin mal ve hizmet alırken yaptıkları davranışları araştırmışlarıdır. Elde ettikleri bulgulara göre; kullanım kolaylığının güven ve fayda değişkenini olumlu etkilediği, risklerin ise bu değişkenleri olumsuz etkilediği görülmüştür. Kim, Chung ve Lee (2011) ise tatil turları üzerine bir çalışma yapmıştır. Çalışma sonucu elde edilen verilere göre; tatil turlarına katılan turistlerin firmaya duydukları güvenin ve turun işlevinin satın alma öncesi güven duygusuna pozitif bir etkisi olduğu anlaşılmıştır. Maliyet değişkeninin ise hiçbir etkisi bulunmamaktadır.

Smith vd. (2013) ise Norveçli, Amerikalı ve Alman öğrencilerin internet üzerinden alışverişlerine ilişkin bir çalışma gerçekleştirmiştir. Bilişsel düzey her ülkede kullanışlılığı ve kullanım kolaylığını etkilerken Almanya' da duyusal katılım ile davranışsal niyetin birbirini etkilemediği gözlemlenmiştir.

Abbas ve Rouibah (2011), Kuveyt'te Mobil telefonların tüketiciler tarafından benimsenme düzeylerini araştırmıştır. 151 kişi üzerine geliştirilen çalışmada sübjektif normlar, kullanışlılık ve kolaylığın mobil telefon kullanımını etkilediği görülmüştür. Bunun yanında imaj, ilişki, çıktı kalitesi gibi dış etkenler ise dolaylı bir etkiye sahip gözükmektedir. Hong, Thong ve Tam'ın (2006) mobil internet kullanımı üzerine Yapısal Eşitlik Modellemesiyle gerçekleştirdikleri çalışmada Teknoloji Kabul Modeli, Hibrit Modeller ve Bilgi Teknolojilerinde Bekleme-Teyit Modeli ile karşılaştırmıştır. Cheong ve Park'ın (2005) öğrenciler üzerine yaptığı çalışmada mobil internet kullanımı yenilikçilik, kalite gibi unsurlarla ölçülmüş aralarındaki ilişki regresyon analizine tabi tutulmuştur. Lee vd. (2002) tarafından gerçekleştirilen araştırmada ise sosyal etki, kullanım kolaylığı, fayda, yeterlilik gibi özelliklerin mobil internet kullanımını kolaylaştırdığı ve onun üzerinde pozitif bir etkiye sahip olduğu görülmüştür.

Ülkemizde yapılan çalışmalarda Uğur ve Turan (2016) Teknoloji Kabul Modelini geliştirerek yeni bir model önerisinde bulunmuştur. Yapılan çalışmada gereksinimler değişkeni modele eklenmiş ayrıca performans beklentisi ve algılanan fayda ayrı başlıklar halinde ele alınmış böylece Mobil Uygulama Kabul Modeli adı altında yeni bir model ortaya konmuştur. Çetinsöz (2015) Turizm pazarlaması kapsamında 358 üniversite personeli üzerine bir çalışma gerçekleştirmiş, kullanım kolaylığı ve güvenin yerli turistlerin e-satın alma davranışları üzerine olumlu etkiye sahip olduğunu ancak algılanan riskin satın alma davranışını negatif yönde etkilediğini bulmuştur. Şıklar, Tunalı ve Gülcan'ın (2015) 363 üniversite öğrencisinden elde ettikleri 
ve LISREL 8.80 programını kullanarak yaptıkları çalışmaya göre konuyla ilgili daha önceki yapılan çalışmaların aksine kullanım kolaylığının algılanan kullanışlılığı etkilemediği sonucuna ulaşmışlardır. Ayrıca yakınsama değişkeninin niyet ve tutumla ilişkili olduğunu bulmuşlardır. Turan ve Haşit'in 2014 yılında sınıf öğretmenlerinin bilgi iletişim teknolojilerinin kabulüne yönelik yaptıkları çalışmada ise kullanım kolaylığı ve faydanın tutum ile niyet üzerinde anlamlı bir etkisi olduğu görülmüştür. Kalyoncuoğlu (2018) yaptığı çalışmada sanal kart kullanımını Teknoloji Kabul Modeli çerçevesinde incelemiştir. Elde ettiği verilere göre tüketicinin algılanan fayda, algılanan kullanım kolaylığı, tutum ve davranışsal niyet düzeyinin önemli belirleyici etkileri olduğu sonucuna ulaşmıştır. Özbek vd. (2014) yaptıkları çalışmada kişilik özelliklerinin Teknoloji Kabul Modeline etkisini araştırmışlardır. Çıkan sonuçlara göre algılanan kullanışlılık ile ve algılanan kullanım kolaylığı değişkenlerinin aracılık etkisi ortaya konulmuştur. Göğüş (2014) yaptığı çalışmada Teknoloji Kabul Modelini kullanarak değiştirme maliyetinin müşteri sadakati üzerindeki etkisini incelemiştir. Elde ettiği sonuçlara göre, değiştirme maliyeti kullanma eğilimi ve davranışsal sadakat üzerinde olumlu yönde etki etmektedir. Ayrıca algılanan kullanım kolaylı̆̆ı ve işlevsellik değiştirme maliyetini pozitif yönde etkilemektedir. Turan (2008) Geliştirilmiş Teknoloji Kabul Modeli (Extended Technology Acceptance Model - E-TAM) önerilerek, bireylerin teknoloji kullanma veya kullanmama nedenleri, internet üzerinden alışveriş özelinde araştırılmıştır. Zengin ve Özkil (2017) teknoloji kabulü ve kullanım faktörlerinin mobil reklam kullanma niyeti üzerine etkisini incelemiştir. Elde edilen sonuçlara göre algılanan eğlencenin mobil reklam kullanma niyeti üzerinde en güçlü etkiye sahip olan teknolojinin kabulü ve kullanımının birleştirilmiş teorisi (TKKBT) boyutu olduğunu ortaya koymuşlardır.

\section{YÖNTEM}

\subsection{Katılımcıların Demografik Özelliklerine İlişkin Tanımlayıcı Bilgiler}

Ankete katılan kişilerin 190'ı erkek 130'u kadınlardan oluşmaktadır. Katılımcıların \%47'si 20 ile 30 yaş arasındadır, \%55'i üniversite mezunu, \%25'i 2000-3000 TL gelire sahiptir. Evlilerin oranı \%32'i bekârların oranı ise \%68'dir. Katılımcıların \%19'u memur, \%14'ü serbest meslek çalışanlarından oluşmaktadır.

\subsection{Araştırma Modeli ve Hipotezler}

Araştırmanın modeli için Teknoloji Kabul Modelleri incelenmiş bunlar arasından Niemelä-Nyrhinen ve Leskinen'in (2014) modeli çalışmada kullanılmıştır. Teknoloji Kabul Modelleri sürekli değişen teknolojik gelişmelerle tüketiciler arasındaki ilişkiyi incelemek için oluşturulmuştur. İlk yıllarda oluşturulan modellerde çalışanların bilgi teknolojisini nasıl algıladığına dair çalışmalar yapılmış olsa da (Venkatesh ve Davis, 2000) ilerleyen y1llarda tüketicilerin teknoloji kabulüne dönük araştırmalar gerçekleştirilmiş ve bu amaçla Teknoloji Kabul Modelleri kullanılmıştır (Moon ve Kim, 2001; Dabholkar ve Bagozzi, 2002; Van der Heijden, 2003; Pavlou, 2003; Curran ve Meuter, 2005; Kim ve Forsythe, 2009).

Teknoloji Kabul Modeli ilk ortaya çıktığında yalnızca algılanan kullanışlılığın algılanan kullanım kolaylığıyla ilişkisini incelemektedir (Davis vd., 1989). Bu oldukça basit ve kullanışlı modele (Venkatesh ve Davis, 2000) Davis vd. (1992) zevk duyma kısmını da eklemiştir. Teknolojinin insanların daha çok hedonik ve hazcı yönlerine hitap ettikleri düşünüldüğünde bu katkı oldukça mantıklı görülmektedir. Ayrıca kullanım kolaylı̆̆ı da zevk'i etkilemektedir. Çünkü kullanımı kolay olan bir teknolojinin daha fazla mutluluk ve haz verdiği düşünülebilir (Teo vd., 1999).

Çalışmanın modeli şekil 3'te gösterilmektedir.



Şekil 3. Teknoloji Kabul Modeli (Kaynak: Niemelä-Nyrhinen ve Leskinen, 2014: 4) 
Modele göre "Algılanan Kullanım Kolaylığı" tüketicilerin bir teknolojiyi çok fazla gayret sarf etmeden kullanabilmesini göstermektedir. Yapılan çalışmalarda algılanan kullanım kolaylığının kullanma niyetini etkilediği görülmektedir (Venkatesh ve Davis, 2000).

Algılama bir kişinin çevresinde olan biten nesneleri uyaranlar yardımıla bilmesi, anlamlandırması demektir (www.iticu.edu.tr). Fayda ise bir nesneden elde edilen yarardır. Algilanan Fayda (AF) mobil cihazlardan elde edilen öznel faydayı göstermektedir. Yapılan çalışmalarda algılanan fayda değişkeninin kullanım niyeti ve tutumlar üzerinde önemli bir etkiye sahip olduğu görülmüştür. Tüketicilere fayda veren faktörlerin anlaşılması için onu etkileyen unsurların bilinmesi gerekmektedir (Kaya ve Tekin, 2003).

Özellikle teknolojik ürünlerde bir ürün ya da hizmetin kullanımına etki eden en önemli faktörlerden biri eğlencedir. Tüketiciler sevdikleri ve kullanırken hâz duydukları ürünleri tercih etmektedirler. Yeni gelişen teknolojiye uyum sağlamada ve satın alma niyetinde hedonik faktörler giderek artan bir öneme sahip olmaktadır. Çalışmada bu nedenle klasik modellerden biraz daha farklı olan bir Teknoloji Kabul Modeli kullanılmıştır.

Tüketicilerin mobil uygulamaları kullanma niyetleri üzerine etki eden birçok faktör bulunmaktadır. Bu faktörlerin ne oranda etki ettiği çalışmanın ana sorusunu oluşturmaktadır. Literatürde kullanım niyetine etki eden faktörler üzerinde durulmuş, çoğu çalışmada algılanan kullanım kolaylığı ve faydanın tutumu oluşturduğu bu tutumun ise kullanım niyetini etkilediği görülmüştür (Aktaş, 2007).

Literatürden elde edilen bilgiler ışığında oluşturulmuş hipotezle şöyledir;

Hı: Mobil Uygulamalar İçin Algılanan Kullanım Kolaylığı (AKK) Algılanan Faydayı (AF) artırmaktadır.

H2: Mobil Uygulamalar İçin Algılanan Kullanım Kolaylığı (AKK) Eğlenmeyi (E) arttırmaktadır.

H3: Mobil Uygulamalar İçin Algılanan Kullanım Kolaylığı (AKK) Kullanma Niyetini (KN) artırmaktadır.

H4: Mobil Uygulamalar İçin Algılanan Fayda (AF) Eğlenmeyi (E) arttırmaktadır.

H5: Mobil Uygulamalar İçin Algılanan Fayda (AF) Kullanma Niyetini (KN) arttırmaktadır.

H6: Mobil Uygulamalar İçin Eğlenme (E) Kullanma Niyetini (KN) arttırmaktadır.

\section{3. Örneklem ve Veri Toplama Aracı}

Çalışmada veri toplama yöntemi olarak anketten yararlanılmıştır. Anket formu oluşturulurken NiemeläNyrhinen ve Leskinen'in (2014) çalışmaları temel alınarak sorular oluşturulmuştur. Anket dağıtılmadan önce mobil uygulamaları aktif bir şekilde kullanan çeşitli yaş ve gelir gruplarından kolayda örneklem metoduyla 30 kişilik bir grup belirlenerek pilot çalışma yapılmış ve anket formu son haline getirilmiştir.

Anket kendi içerisinde 2 bölümden oluşmaktadır. İlk bölümde 13 soru yer almakta ve tüketicilerin mobil uygulamalara karşı algıları ölçülmektedir. İkinci bölümde ise farklı tüketici kesimlerinin teknoloji kabul modeline yaklaşımlarını belirlemek ve karşılaştırmalı analizler yapabilmek için demografik bilgilerin bulunduğu sorulara yer verilmiştir. Ankette 5 'li Likert ölçeği ("1=Hiç Katılmıyorum", "5=Tamamen Katılıyorum") kullanılmıştır.

Araştırmada veri toplama metodu olarak kolayda örneklem yöntemi kullanılmış, 2.2.2018 ile 1.3.2018 tarihleri arasında 350 tane anket Afyonkarahisarın il merkezi ve ilçelerine dağıtılmıştır. Genel kabul gören olayın gerçekleşme olasılığ $\mathrm{p}=0,3$ ve gerçekleşmeme olasılığı $\mathrm{q}=0,7$ değerleri dikkate alındığında, \%95 güven aralığında ve $\pm 0,05$ 'lik sapma oranı ile örneklem sayısı hesaplandığında örneklem sayısı 323 bulunmuştur (Erdoğan, 2004: 50). Eksik ve hatalı doldurulan 30 anket çalışma kapsamı dışında tutulmuş, 320 anket çalışmaya dâhil edilmiştir.

\subsection{Verilerin Analizi}

Çalışmada Teknoloji Kabul Modeli Yapısal Eşitlik Modellemesi (YEM) yardımıyla test edilmiştir. Yapısal Eşitlik Modeli birçok istatistiksel analizin aynı anda yapılmasına imkân tanıyan bir yöntemdir (Arı, Yılmaz ve Başkan, 2015). YEM, gözlenmeyen değişkenlerin arasında nedensellik çerçevesinde bir bağ var olduğunu ve bunların gözlenebilen değişkenler vasıtasıyla ölçülebileceğini iddia eder (Yılmaz, 2004).

Yapısal eşitlik modelinde çok sayıda modelin uygunluğunu belirleyen çok sayıda uyum indeksi bulunmaktadır. YEM'de en sık kullanılan model indeksleri Kikare/sd, RMSEA, CFI ve GFI'dır (SchermellehEngel vd. 2003). 
Çalışmada gizli değişkenler arasındaki ilişkiler, uyum ölçütleri, Path Diyagramı, ki kare değeri, yapı güvenilirliği, korelasyon ilişkileri LISREL hazır yazılımı kullanılarak test edilmiştir. Demografik değişkenlerin karşılaştırmalı analizinde ise SPSS programından faydalanılmıştır.

\section{BULGULAR}

\subsection{Açıklayıcı Faktör Analizi}

Güven analizi açısından iç tutarlılık yöntemini temel alan alfa katsayısı hesaplanmıştır. Bu katsayı anketteki ifadelerin varyanslarının genel varyans oranlanmasıyla ile oluşan standart değişimi olarak gösterilmiştir (Özdamar, 1999).

Ölçme aracının güvenilirliğini belirlemek için Cronbach Alfa analizi yapılmış, güven katsayısı 0,91 olarak hesaplanmıştır. Bu sonuca göre anket güvenilirliği oldukça yüksektir (Doğan, Şen, Yılmaz, 2015: 11).

Tablo 1'de tüketicilerin mobil uygulamalara karşı görüşlerine ilişkin faktör analizi sonuçları görülmektedir. Faktör analizi sonucunda değişkenlerin toplam varyansın \%74,256'sini açılayan 4 faktör altında toplandığ 1 görülmektedir. Ayrıca her faktörün Cronbach Alfa katsayısı 0,787-0,864 arasında bulunmuştur ve güvenilirliğinin yüksek olduğu görülmektedir (Yilmaz ve Doğan, 2016: 200).

Tablo 1'de yer alan Kaiser-Meyer-Olkin (KMO) testi, örneklem büyülüğünün yeterliliğini ölçmek için, Bartlett Küresellik Testi ise çok değişkenli normalliğin göstergesi ve değişkenler arasındaki ilişkinin yeterliliğini ölçmek amacıyla tabloda yer almıştır (Pett, Lackey ve Sullivan, 2003: 77, Kaya, 2013: 181). Çalışmada Kaiser-Meyer-Olkin değeri 0,918 olduğundan örneklem hacminin yeterliliğini Bartlett testi ise faktör analizinin kullanılabilir olduğunu (Çakır, 2014: 5) göstermektedir ( $\chi 2=2392,389$ ve $p<0,001)$.

Tablo 1. Tüketicilerin Mobil Uygulamalara Karşı Görüşlere Yönelik Faktör Analizi

\begin{tabular}{|c|c|c|c|c|c|}
\hline Faktörler / Maddeler & 1 & 2 & 3 & 4 & $\begin{array}{l}\text { Cronbach's } \\
\text { Alpha }\end{array}$ \\
\hline Faktör: Kolaylık (AKK) & & & & & ,787 \\
\hline SORU 1. Mobil servisleri öğrenmek benim için kolaydır & ,845 & & & & \\
\hline SORU 2. Mobil servisler konusunda becerikliyimdir & 837 & & & & \\
\hline SORU 3. Bana uygun uygulamayı bulmakta zorlanmıyorum & ,722 & & & & \\
\hline Faktör: Algılanan Fayda (AF) & & & & &, 842 \\
\hline $\begin{array}{l}\text { SORU 4. Mobil cihazlardaki uygulamalar bazı hizmetlere daha } \\
\text { kolay ulaşmamı sağlıyor }\end{array}$ & & ,682 & & & \\
\hline SORU 5. Mobil cihazlardaki uygulamalar kullanışlıdır & & ,776 & & & \\
\hline $\begin{array}{l}\text { SORU 6. Mobil cihazlardaki uygulamalar işlemlerimin daha } \\
\text { hızlı olmasını sağlıyor. }\end{array}$ & & 783 & & & \\
\hline $\begin{array}{l}\text { SORU 7. Mobil cihazlardaki uygulamalar bazı konularda } \\
\text { performansımın artmasını sağliyor. }\end{array}$ & & ,703 & & & \\
\hline Faktör: Eğlenme (E) & & & & & 864 \\
\hline SORU 8. Mobil uygulamaları kullanmak eğlencelidir & & & 811 & & \\
\hline SORU 9. Mobil uygulamaları kullanmak keyif vericidir & & & 852 & & \\
\hline SORU 10. Mobil uygulamaları kullandığımda iyi vakit geçiririm. & & & 830 & & \\
\hline Faktör: Niyet (KN) & & & & & 840 \\
\hline $\begin{array}{l}\text { SORU 11. Mobil servisleri önümüzdeki yıllarda da kullanmayı } \\
\text { düşünüyorum. }\end{array}$ & & & &, 577 & \\
\hline $\begin{array}{l}\text { SORU 12. Mobil servilerle farklı uygulamaları da kullanmayı } \\
\text { düşünüyorum }\end{array}$ & & & & ,523 & \\
\hline $\begin{array}{l}\text { SORU 13. Mobil servisleri önümüzdeki yıllarda daha fazla } \\
\text { kullanmayı düşünüyorum. }\end{array}$ & & & & ,524 & \\
\hline Faktörlere İlişkin Aritmetik Ortalama Değerleri & 3,77 & 4,00 & 3,78 & 3,83 & \\
\hline Faktörlere İlişkin Standart Sapma Değerleri & 1,21 & 1,11 & 1,11 & 1,14 & \\
\hline Kaiser-Meyer-Olkin (Örneklem Yeterliliği) & \multicolumn{5}{|c|}{,918 } \\
\hline $\begin{array}{l}\text { Bartlett Testi (Ki kare Değeri) } \\
\text { Anlamlılık Düzeyi }\end{array}$ & \multicolumn{5}{|c|}{$\begin{array}{c}2392,389 \\
<0,001\end{array}$} \\
\hline Açılanan Varyans & \multicolumn{5}{|c|}{$\% 74,256$} \\
\hline
\end{tabular}

\section{2. Ölçüm Modeline İlişkin Sonuçlar}


YEM'in en önemli varsayımlarından biri olan çok değişkenli normallik varsayımı için, Mardia (1970) testine dayanarak, LISREL aracılığı ile yapılan çok değişkenli normallik testi sonucunda, Mardia Captcha değeri 748 $(p<0,001)$ olarak hesaplanmıştır. Yani veri seti çok değişkenli normallik varsayımını sağlamamaktadır. Bu nedenle araştırmada parametre tahmin yöntemi olarak "Robust Maximum Likelihood" kullanılması uygun görülmüştür.

Ölçüm modeline ait uyum iyiliği değerlerinin $\left(p<0,001, x^{2}=76.80\right.$, Serbestlik Derecesi $(s d)=59, x^{2} / s d=1,30$, RMSEA=0,031, CFI= 1.00, GFI=0,92, IFI= 1,00, RFI=0,99) kabul edilebilir değerlerin üstünde olduğu (Schermelleh-Engel, Moosbrugger ve Müller, 2003: 52; Gürbüz ve Şahin, 2016: 337, Çokluk, Şekercioğlu ve Büyüköztürk, 2014: 271-272) böylece kuramsal olarak verilerin araştırmada kullanılan ölçeğe uyum sağladığ1 anlaşılmıştır.

Araştırma modeline ait faktörler, faktörlere ait yapı geçerliliği ve açıklanan varyans değerleri, standart yükler, $\mathrm{t}$ değerleri, $\mathrm{R}^{2}$ değerleri ve Cronbach's Alpha değerleri Tablo 4'de verilmiştir. Yakınsaklık Geçerliliğinin sağlanabilmesi için üç kriter söz konusudur. İlk olarak, gizil değişkenlere ait her bir gözlenen değişkenin standart faktör yükünün $0,5^{\prime}$ den büyük olması ve istatistiksel olarak anlamlı olması gerekmektedir (Fornell ve Larcker, 1981). İkinci olarak, her bir yapı için Yapı Güvenilirliği (Composite Reliability - CR) değerinin 0,7'den büyük olması gerekmektedir (Hair et al, 1998). Son olarak, her yapı için Ortalama Açılanan Varyans (Average Variance Extracted - AVE) değerinin 0,5'den yüksek olması (Fornell ve Larcker, 1981) gerekmektedir (Huang vd., 2013). Çalışmanın yakınsaklık geçerliliği kontrol edildiğinde, standart faktör yüklerinin 0,64 ile 0,94 arasında değiştiği, CR değerlerinin ise 0,85 ve üstü değerler aldığ 1 gözlenmiştir. AVE katsayılarından da ikisi 0,58 ile 0,67 arasında değiştiği gözlenmiştir. Bu nedenle yapıların yakınsaklık geçerliliği sağlanmıştır.

Ölçüm modelinin ayırt edici geçerliliğinin sağlanması için her bir yapının AVE değerinin karekökünün, o yapı ile diğer yapılar arasındaki korelasyonunun karşılaştıılmasıyla kontrol edilir. Bu karşılaştırmalar sonucunda AVE'nin karekök değerleri daha büyük ise ayırt edici geçerlilik sağlanmış olur (Fornell ve Larcker, 1981). Tablo 2'de ölçüm modelinin ayırt edici geçerliliği verilmiştir. Buradan görüldügüu üzere, AVE'nin karekökü tüm yapılar için korelasyonlarından daha büyüktür. Dolayısıyla ayırt edici geçerlilik sağlanmış olur.

Tablo 2. Korelasyonlar ve AVE katsayılarının Karşılaştırılması

\begin{tabular}{lcccc}
\hline Yapilar & 1 & 2 & 3 & 4 \\
1.E & $\mathbf{0 , 8 1}$ & $\mathbf{0 , 7 6}$ & $\mathbf{0 , 8 2}$ & $\mathbf{0 , 7 6}$ \\
2.KN & 0,78 & & & \\
3.AKK & 0,52 & 0,67 & & \\
4.AY & 0,66 & 0,75 & 0,75 & $\mathbf{0 , 5 8}$ \\
\hline AVE & $\mathbf{0 , 6 6}$ & $\mathbf{0 , 5 9}$ & $\mathbf{0 , 6 7}$ \\
\hline
\end{tabular}

Not: Korelasyon Arasındaki Köşegen elemanlar AVE'nin kareköküdür. Tüm korelasyonlar p<0,01 düzeyinde anlanmalıdır.

\section{3. Önerilen Modele İlişkin Yapısal Eşitlik Analizi Sonuçları}

Çalışmada tüketicilerin gelişen teknolojilere kabullerini anlamak için Teknoloji Kabul Modeli kullanılmıştır. Birçok kabul modeli arasından Niemelä-Nyrhinen ve Leskinen'in (2014) modeli temel alınmış, bu modele literatüre dayanarak (Davis vd. 1992) zevk duyma kısmı da eklenmiştir. Çalışmada kullanılan Teknoloji Kabul Modeli; Algılanan Kullanım Kolaylı̆̆ı (AKK), Algılanan Fayda (AF), Eğlenme (E) faktörünün Kullanma Niyeti $(\mathrm{KN})$ üzerindeki etkisini ölçmektedir. Bunlar arasındaki ilişki Yapısal Eşitlik Modeli Kullanılarak (YEM) araştırılmaya çalışılmıştır.

4 faktörden oluşan çalışmanın uyum ölçütleri Tablo 3'de gösterilmektedir. Araştırmanın uyumunu gösteren kikare değeri (x²/sd) olarak hesaplanır (Hair, vd., 1998; Jöreskog ve Sörbom, 1996; Schermelleh-Engel vd., 
2003; Raykov ve Marcoulides, 2006). Yapılan çalışmada kikare/sd 1,74 bulunmuş ve çıan sonucun iyi uyum değerleri arasında olduğu görülmüştür. Tabloya göre ortaya konan model ile standart değerler karşılaştırıldığında elde edilen sonuçların tümünün kabul edilebilir değerler arasında olduğu görülmektedir.

Tablo 3. Yapısal Eşitlik Modeline İlişkin Uyum Ölçütleri

\begin{tabular}{|c|c|c|c|c|}
\hline Uyum Ölçüsü & İyi Uyum & $\begin{array}{c}\text { Kabul Edilebilir } \\
\text { Uyum }\end{array}$ & Model Değeri & Uyum \\
\hline$X^{2} / s d$ & $0 \leq \mathrm{X}^{2} / \mathrm{sd}<2$ & $2 \leq \mathrm{X}^{2} / \mathrm{sd}<3$ & 1,74 & İyi Uyum \\
\hline RMSEA & $\begin{array}{c}0 \leq \text { RMSEA }< \\
0,05\end{array}$ & $\begin{array}{c}0,05 \leq \text { RMSEA } \leq \\
0,08\end{array}$ & 0,031 & İyi Uyum \\
\hline NFI & $\begin{array}{c}0,95<\mathrm{NFI} \leq \\
1,00\end{array}$ & $0,90 \leq \mathrm{NFI} \leq 0,95^{\mathrm{a}}$ & 0,98 & İyi Uyum \\
\hline NNFI & $\begin{array}{c}0,97<\mathrm{NNFI} \leq \\
1,00\end{array}$ & $\begin{array}{c}0,95 \leq \mathrm{NNFI} \leq \\
0,97^{\mathrm{b}}\end{array}$ & 0,99 & İyi Uyum \\
\hline CFI & $0,97<\mathrm{CFI} \leq 1,00$ & $0,95 \leq \mathrm{CFI} \leq 0,97$ & 1,00 & İyi Uyum \\
\hline GFI & $0,95<\mathrm{GFI} \leq 1,00$ & $0,90 \leq \mathrm{GFI} \leq 0,95$ & 0,92 & $\begin{array}{c}\text { Kabul Edilebilir } \\
\text { Uyum }\end{array}$ \\
\hline AGFI & $\begin{array}{c}0,90<\text { AGFI } \leq \\
1,00\end{array}$ & $\begin{array}{c}0,85 \leq \mathrm{AGFI} \leq \\
0,90\end{array}$ & 0,88 & $\begin{array}{c}\text { Kabul Edilebilir } \\
\text { Uyum }\end{array}$ \\
\hline
\end{tabular}

\subsection{Geçerlilik ve Güvenilirlik Analizi}

Tablo 4'de araştırma modelinin yapısal eşitlik sonuçları görülmektedir. Tablo 4'e bakıldığında yapı güvenilirliğinin, açıklanan varyansın kabul edilebilir bir düzeyde olduğu görülmektedir. Dışsal değişkenle onu açılayan gözlenen değişkenlerin ilişkilerine bakıldığında soru 1 ve 2'nin kolaylık faktörünü daha iyi açıkladığı görülmektedir. Algılanan Fayda faktörünü en iyi açıklayan 5. soru, eğlenme faktörünü 9. soru, niyet faktörünü ise 11. sorudur. Anketteki tüm gözlenen değişkenlerin gizil değişenlere ait faktörleri açıkladığı görülmektedir.

Tablo 4. Araştırma Modeli İçin Yapısal Eşitlik Modeli Sonuçları

\begin{tabular}{|c|c|c|c|c|c|c|}
\hline & Standart Yükler & $\begin{array}{c}\text { Standart } \\
\text { Hata }\end{array}$ & t-değeri & $\mathbf{R}^{\mathbf{2}}$ & $\begin{array}{c}\text { Yap1 } \\
\text { Güvenirlil } \\
\text { iği }\end{array}$ & $\begin{array}{c}\text { Açılanan } \\
\text { Varyans }\end{array}$ \\
\hline Faktör: Kolaylık (AKK) & & & & & 0,85 & 0,67 \\
\hline SORU 1 & 0,90 & 0,041 & 34,95 & 0,81 & & \\
\hline SORU 2 & 0,88 & 0,067 & 26,63 & 0,78 & & \\
\hline SORU 3 & 0,64 & 0,011 & 14,09 & 0,41 & & 0,58 \\
\hline $\begin{array}{c}\text { Faktör: Alg1lanan } \\
\text { Fayda (AF) }\end{array}$ & & & & & 0,88 & \\
\hline SORU 4 & 0,83 & 0,061 & & 0,69 & & \\
\hline SORU 5 & 0,84 & 0,051 & 22,11 & 0,71 & & \\
\hline SORU 6 & 0,81 & 0,052 & 23,47 & 0,66 & & \\
\hline SORU 7 & 0,74 & 0,064 & 17,76 & 0,55 & & \\
\hline Faktör: Eğlenme (E) & & & & & 0,90 & \\
\hline SORU 8 & 0,89 & 0,043 & & 0,79 & & \\
\hline SORU 9 & 0,94 & 0,026 & 27,21 & 0,89 & & \\
\hline SORU 10 & 0,78 & 0,064 & 18,22 & 0,60 & & \\
\hline Faktör: Niyet (KN) & & & & & 0,88 & \\
\hline SORU 11 & 0,86 & 0,069 & & 0,75 & & 0,59 \\
\hline SORU 12 & 0,80 & 0,061 & 21,33 & 0,64 & & \\
\hline SORU 13 & 0,85 & 0,052 & 23,23 & 0,73 & & \\
\hline
\end{tabular}

Yapılan t testi sonucunda 1, 4, 5 ve 6 . hipotezlerin desteklendiğini 2 ve 3. hipotezlerin ise desteklenmediği anlaşılmaktadır. Buna göre;

Dışsal gizil değişken olan AKK faktörü $\mathrm{AF}^{\prime}$ yi 0,75 oranında etkilemektedir. Bunun anlamı mobil araçların kullanım kolaylığında yaşanan bir birimlik artış mobil hizmetlerin faydasında 0,75 artışa neden olmaktadır. Ankete katılan kişilerin mobil hizmetleri kolaylıkla kullanmaları, bu hizmetlerin faydalı olduğuna yönelik inancı arttırmakta, tüketici uyumunu kolaylaştırmaktadır. 


\section{A. Uyar 11/1 (2019) 687-705}

AKK ile E ve AKK ile KN arasında istatistiksel olarak anlamlı bir ilişki bulunamamıştır. AKK, E faktörünü ve $\mathrm{KN}$ faktörünü etkilememektedir.

AF faktörü E değişkenini 0,62 oranında etkilemektedir. Mobil uygulamaların faydalı olduğunu düşünen kişiler aynı zamanda bu uygulamaları eğlenceli de bulmaktadır. AF ile E arasında orta şiddette pozitif bir ilişki bulunmaktadır.

$\mathrm{AF}$ ile $\mathrm{KN}$ arasında 0,57 oranında pozitif yönlü bir ilişki bulunmaktadır. Bunun anlamı kullanım faydasında oluşacak bir birimlik artış kullanım niyetini 0,57 oranında arttırmaktadır. E ile $\mathrm{KN}$ arasında ise 0,39 oranında diğer ilişkilere göre nispeten daha düşük bir ilişkisi bulunmaktadır.

Çıkan sonuçlar birlikte değerlendirilerek tüm değişkenler göz önüne alındığında en güçlü ilişkinin AKK ile AF arasında olduğu görülmektedir. Dışsal gizil değişen olan kullanım kolaylığı en fazla faydayı etkilemektedir. Modele göre mobil uygulamaları kolaylıkla kullanan kişiler belki daha fazla uygulama kullandıkları ya da farklı uygulamalar kullanabildiklerinden dolayı mobil uygulamaları faydalı bulmaktadır.

Tablo 5. Yapısal Modelin Hipotez Testi Sonuçları $(n=320)$

\begin{tabular}{llclll}
\hline Hipotezler & $\begin{array}{c}\text { Doğrudan } \\
\text { Etkiler }\end{array}$ & Standart Yükler & Standart Hata & $\mathrm{t}$ & Sonuçlar \\
$\mathrm{H} 1$ & AKK->AF & 0,75 & 0,049 & $15,32^{*}$ & Desteklendi \\
$\mathrm{H} 2$ & AKK->E & 0,05 & 0,085 & 0,47 & Desteklenmedi \\
$\mathrm{H} 3$ & AKK->KN & 0,04 & 0,085 & 0,46 & Desteklenmedi \\
$\mathrm{H} 4$ & AF->E & 0,62 & 0,072 & $5,24^{*}$ & Desteklendi \\
$\mathrm{H} 5$ & AF->KN & 0,57 & 0,011 & $5,33^{*}$ & Desteklendi \\
$\mathrm{H} 6$ & E->KN & 0,39 & 0,072 & $5,40^{*}$ & Desteklendi \\
\hline
\end{tabular}

\begin{tabular}{ll}
\hline Açıllama Değerleri & $\mathrm{AF}=0,75^{*} \mathrm{AKK}, \mathrm{R}^{2}=0,57$ \\
& $\mathrm{E}=0,62^{*} \mathrm{AF}+0,055^{*} \mathrm{AKK}, \mathrm{R}^{2}=0,44$ \\
& $\mathrm{KN}=0,57^{*} \mathrm{AF}+0,39^{*} \mathrm{E}+0,039^{*} \mathrm{AKK}, \mathrm{R}^{2}=0,81$
\end{tabular}

* $p<0,05$ anlaml1l1k düzeyinde, $x^{2}=102,89 \mathrm{sd}=59, \mathrm{x}^{2} / \mathrm{sd}=1,74, \mathrm{RMSEA}=0,064, \mathrm{CFI}=0,99, \mathrm{GFI}=0,95, \mathrm{SRMR}=0,038, \mathrm{PGFI}=0,62$.

LISREL yazılımıyla elde edilmiş YEM diyagramı Şekil 4'de gösterilmektedir. Şekilde algılanan kullanım kolaylığı dışsal gizil değişkendir. Fayda, eğlenme, niyet gibi faktörler ise içsel gizil değişkenleri meydana getirmektedir. 


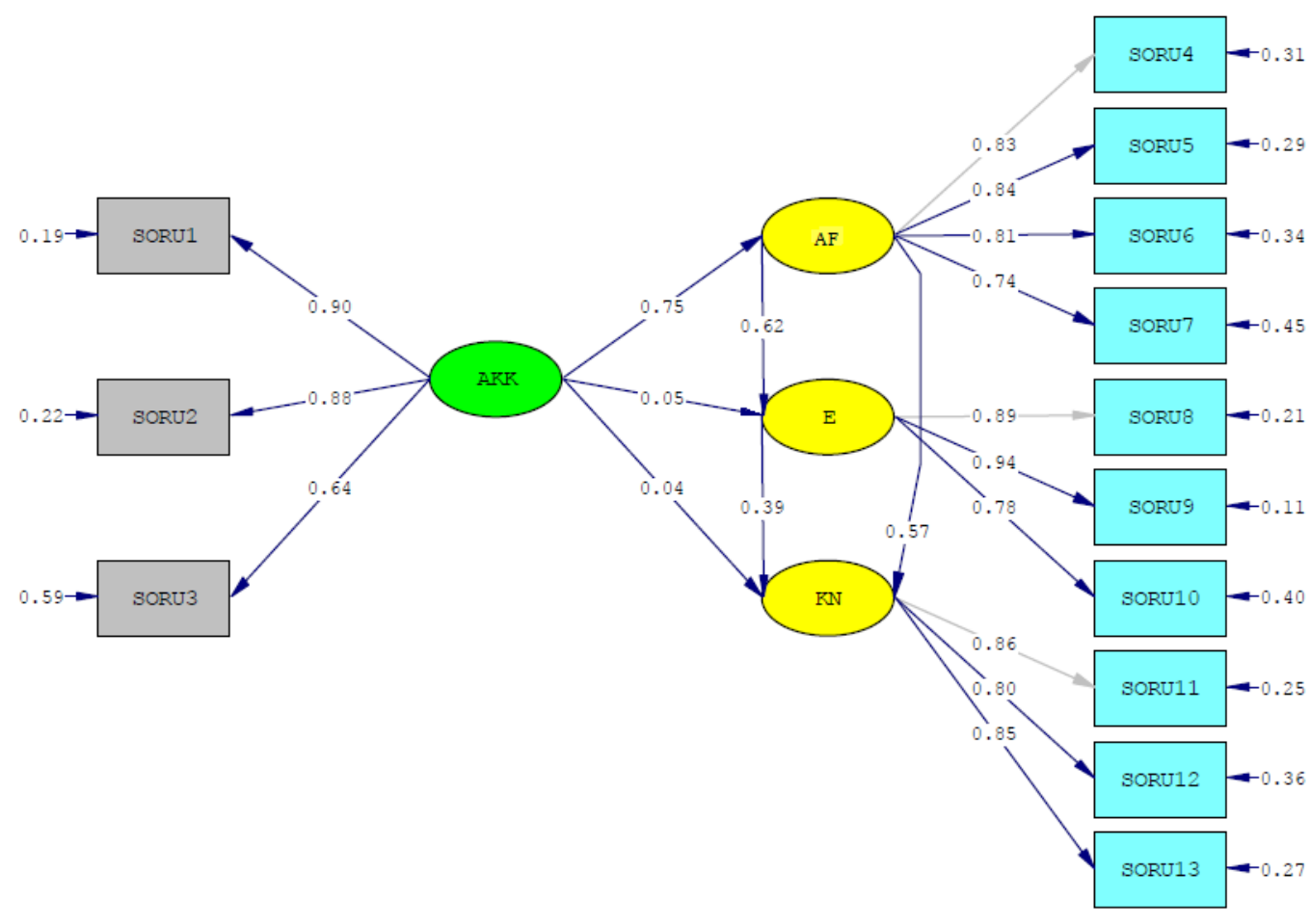

Şekil 4. Modelin YEM Diyagramı

\subsection{Katılımcıların Demografik Özelliklerine Göre Teknoloji Kabul Modelinin İncelenmesi}

Katılımcıların mobil teknoloji uyumuna yönelik görüşlerini cinsiyete göre karşılaştıran Tablo 5'e göre kadınlar erkeklere göre mobil uygulamaları kullanmayı daha eğlenceli bulmakta, daha güzel vakit geçirdiklerini düşünmektedirler. Ancak erkekler kadınlara oranla mobil uygulamaları gelecekte daha fazla kullanmak istemekte ayrıca farklı servisleri de deneyimlemek istemektedir. Bu nedenle ilerleyen dönemlerde erkelerin kadınlara oranla mobil uygulamalar konusunda da istekli oldukları söylenebilir.

Tablo 5. Katılımcıların Teknoloji Uyumuna Yönelik Görüşlerinin Cinsiyete Göre Karşılaştırılmasına Yönelik t Testi Sonucu

\begin{tabular}{|c|c|c|c|c|c|c|}
\hline Boyutlar & Cinsiyet & $\mathbf{N}$ & $x$ & ss & $\mathrm{T}$ & $\mathbf{P}^{*}$ \\
\hline \multirow{2}{*}{$\begin{array}{l}\text { Mobil uygulamaları kullandığımda iyi vakit } \\
\text { geçiririm }\end{array}$} & Erkek & 190 & 3,65 & 1,233 & \multirow{2}{*}{-780} & \multirow{2}{*}{,030 } \\
\hline & Kadın & 130 & 3,75 & 1,022 & & \\
\hline \multirow{2}{*}{$\begin{array}{l}\text { Mobil servilerle farklı uygulamaları da } \\
\text { kullanmayı düşünüyorum }\end{array}$} & Erkek & 190 & 3,87 & 1,086 & \multirow{2}{*}{2,171} & \multirow{2}{*}{,028 } \\
\hline & Kadın & 130 & 3,59 & 1,212 & & \\
\hline \multirow{2}{*}{$\begin{array}{l}\text { Mobil servisleri önümüzdeki yıllarda daha } \\
\text { fazla kullanmayı düşünüyorum }\end{array}$} & Erkek & 190 & 3,78 & 1,086 & \multirow{2}{*}{,788 } & \multirow{2}{*}{,035 } \\
\hline & Kadın & 130 & 3,68 & 1,212 & & \\
\hline
\end{tabular}

*P $<0.05$ anlamlılık düzeyinde

Tablo 6'da katılımcıların mobil uygulamalara karşı düşüncelerini yaş değişkenine göre karşılaştıran ANOVA testi sonuçları gösterilmektedir. Tabloya göre yaş ilerledikçe algılanan kullanım kolaylığı, fayda, eğlenme ve kullanım niyeti azalmaktadır. Ankete katılan kişiler arasında özellikle 0-30 yaş arasındakilerin teknoloji kabulüne ilişkin değerler genel olarak yüksek çıkmaktadır. 
A. Uyar 11/1 (2019) 687-705

Tablo 6. Katılımcıların Teknoloji Uyumuna Yönelik Görüşlerinin Yaşa Göre Karşılaştırılmasına Yönelik ANOVA Testi Sonucu

\begin{tabular}{ccccccc}
\hline Boyutlar & Yaş & $\mathbf{N}$ & $\mathbf{X}$ & ss & $\mathbf{F}$ & $\mathbf{p}$ \\
Algılanan & $0-20$ & 89 & 3,8090 &, 92781 & & \\
Kullanım & $21-30$ & 152 & 4,0154 &, 89586 & & $<0,001$ \\
Kolaylığ & $31-40$ & 38 & 3,7018 &, 94849 & 11,780 & \\
(AKK) & $41-50$ & 21 & 2,9048 & 1,11626 & & \\
& 51 ve üzeri & 20 & 2,8500 & 1,17715 & & \\
Algılanan & $0-20$ & 89 & 4,1938 &, 65578 & & $<0,001$ \\
Fayda & $21-30$ & 152 & 4,1546 &, 76607 & & \\
(AF) & $31-40$ & 38 & 3,9868 & 1,01666 & 9,346 & \\
& $41-50$ & 21 & 3,3214 &, 99103 & & \\
& 51 ve üzeri & 20 & 3,3375 & 1,16211 & & \\
Eğlenme & $0-20$ & 89 & 3,9438 &, 86928 & & \\
(E) & $21-30$ & 152 & 3,8662 &, 90315 & 3,896 & \\
& $31-40$ & 38 & 3,5877 & 1,16618 & 3,001 \\
Kullanım & $41-50$ & 21 & 3,2063 & 1,23593 & & \\
Niyeti & 51 ve üzeri & 20 & 3,4000 & 1,19257 & & \\
(K) & $0-20$ & 89 & 3,9363 &, 78637 & & \\
& $21-30$ & 152 & 4,0022 &, 85738 & & \\
\hline
\end{tabular}

Tablo 7'de katılımcıların mobil uygulamalara ilişkin görüşlerinin öğrenim durumuna göre karşılaştırılması yer almaktadır. Tabloya göre eğitim seviyesi arttıkça mobil uygulamalara karşı adaptasyon ve uyum yükselmektedir. Üniversite mezunları mobil uygulamaları daha kolay kullanmakta, kullanırken eğlenmekte ve gelecekte bu hizmetleri daha fazla kullanma niyetinde olduklarını söylemektedir.

Tablo 7. Katılımcıların Teknoloji Uyumuna Yönelik Görüşlerinin Öğrenim Durumuna Göre Karşılaştırılmasına Yönelik ANOVA Testi Sonucu

\begin{tabular}{ccccccc}
\hline Boyutlar & Öğrenim & $\mathbf{N}$ & $\mathbf{X}$ & $\mathbf{s s}$ & $\mathbf{f}$ & $\mathbf{p}$ \\
& İlkokul & 27 & 3,0988 & 1,32953 & & \\
Algılanan Kullanım Kolaylı̆̆ & Ortaokul & 41 & 3,4472 & 1,12203 & 7,219 & $<0,001$ \\
(AKK) & Lise & 76 & 3,8904 &, 92598 & & \\
& Üniversite & 176 & 3,9053 &, 90143 & & \\
Algılanan Fayda & İlkokul & 27 & 3,3889 &, 23241 & & \\
$(\mathrm{AF})$ & Ortaokul & 41 & 3,6951 &, 16322 & 10,061 & $<0,001$ \\
& Lise & 76 & 4,1250 &, 09557 & & \\
Eğlenme & Üniversite & 176 & 4,1832 &, 05121 & & \\
(E) & İlkokul & 27 & 3,3580 &, 25345 & & \\
Ortaokul & 41 & 3,4309 &, 17431 & 4,426 & \multirow{2}{*}{, 005} \\
Kullanım Niyeti & Lise & 76 & 3,8728 &, 0664 & & \\
(KN) & Üniversite & 176 & 3,8902 &, 06620 & & $<0,001$ \\
\hline
\end{tabular}

\section{SONUÇ}

Son yıllarda artan teknolojik gelişim baş döndürücü bir boyuta ulaşmıştır. Endüstri 4.0 olarak ifade edilen gelişmeler neticesinde yapay zekadan, 3D yazıcılara, akıllı teknolojilerden, sanal gerçekliğe kadar birçok alanda ilerlemeler yaşanmaktadır. Bu değişim süreci tüketicilerin teknolojik gelişmelere ayak uydurma konusunda sıkıntılar yaşamalarına neden olabilmektedir. Özellikle sesiz kuşak, baby boomers ve $\mathrm{x}$ kuşağı adı verilen ve 1980 öncesi doğan insanlar bu döneme ve onun getirdiği yeniliklere uyum sağmakta zaman zaman zorlanmaktadır. 
Ticari kâr amacı güden ve sürekli bir rekabet ortamı içinde varlık savaşı veren işletmeler müşteri sadakati sağlamak ve daha iyi hizmet vermek için yeni gelişen teknolojilerden faydalanmak istemektedir. İnovasyon en önemli kavramlardan biri haline gelmiştir. Yenilik yapmadan piyasada pazar payını genişletmenin başka bir yolu bulunmamaktadır. Bu nedenle işletmeler tüketicilerin hayatını kolaylaştıracak ve onlara daha yakın olmalarını sağlayan yenilikler yapmak durumunda kalmaktadır. Mobil hizmetler işletmeyle tüketici arasında geliştirilmek istenen ilişki için oldukça kullanışlı ortamlar sağlamaktadır. İnsanlara ulaşmanın en kolay yolu onların devamlı yanlarında bulunan tablet, cep telefonu gibi cihazlara ulaşmaktır. Bu nedenle işletmeler için mobil uygulamaların önemi büyüktür. Mobil cihazlar aynı zamanda kullanıcılar için farklı bazı kolaylıklara da neden olmakta, yol bulmak, hava durumunu öğrenmek, banka işlemleri yapmak, haberleşmek, video izlemek, yabancı dil öğrenmek, sosyal ortamlar sağlamak gibi birçok amaçla kullanılmaktadır. Son yıllarda insanlar tarafından çok yoğun bir şekilde kullanılan mobil uygulamaların yıllık gelirleri 17 milyar dolara, indirilme sayıları 26 milyara yükselmiştir (https://webrazzi.com).

Günlük hayatın önemli bir parçası haline gelen mobil uygulamalara tüketicilerin sağladıkları uyum ve ona bakış açıları bu çalışmanın amacını oluşturmaktadır. Elde edilen veriler insanların mobil uygulamalara adaptasyonunu ve kullanım amacını gösterirken işletmelere ve hizmet sağlayıcılara da mobil uygulamalar açısından bazı ipuçları vermektedir.

Çalışmadan elde edilen verilere göre kullanım kolaylığıyla elde edilen fayda arasında yüksek şiddette doğrusal bir ilişki bulunmuştur. Buna göre mobil hizmetleri kolaylıkla kullanan kişiler bu uygulamalardan daha fazla faydalanmaktadır. Çalışmada eğitim durumu yüksek, genç kişilerin mobil uygulamaları daha kolay kullandıkları ve bunlardan daha çok yararlandıkları söylenebilir. Bu nedenle mobil uygulama hizmeti veren kişi ve kurumların yaşlıları ve eğitim seviyeleri düşük olan kişileri göz önüne alarak kullanımı kolay servis hizmetleri sağlamaları faydalı olacaktır. Çünkü ters ilişkiyle düşünüldüğünde kullanım kolaylığı sağlayamayan kişiler mobil uygulamalardan yeterince faydalanamamaktadır.

Algılanan kullanım kolaylığıyla eğlenme ve kullanım niyeti arasında bir ilişki bulunamamıştır. Bu nedenle mobil hizmetleri kolaylıkla kullanan kişilerin bu hizmetlerden daha çok zevk aldıkları ve ileride daha çok kullanmak istedikleri sonucu çıkmamaktadır.

Mobil uygulamaları faydalı görme ile eğlenme arasında anlamlı bir ilişki bulunmaktadır. Buna göre mobil hizmetleri faydalı gören kişiler eğlenme amacıyla da bu uygulamaları kullanmaktadır. Eğlence kavramının içerisinde güzel vakit geçirme, keyif alma gibi değişkenler olduğundan ve tüketicilerin çoğunluğu bu amaçla mobil uygulamaları kullandığından böyle bir sonucun ortaya çıkması doğaldır.

Algılanan fayda ile kullanım niyeti arasında anlamlı bir ilişki bulunmuştur. Buna göre uygulamaların faydalı görülmesi arttıkça bu uygulamaları kullanma isteği de yükselmektedir. Ayrıca eğlenme istekliliği de kullanım niyetini pozitif yönde arttırmaktadır. Bu nedenle mobil uygulamaları satın alma ve kullanma niyetini kullanım kolaylığı değil eğlenme ve fayda faktörü etkilemektedir. Çünkü şu an mobil hizmetleri yeterince kullanmayan tüketiciler bile ileride bu uygulamaları daha çok kullanma niyetindedir.

Çalışmadan elde edilen demografik faktörlerle teknoloji kabulü karşılaştırıldığında kadınlar ve erkelerin bazı konularda farklılık gösterdikleri anlaşılmaktadır. Erkek kullanıcılar ileride daha fazla mobil hizmet almak isterken kadınlar bu uygulamaları kullanmaktan daha büyük bir keyif duymaktadır. Ayrıca eğitim seviyesi yükseldikçe teknoloji kabulü artmakta, yaş ilerledikçe ise düşmektedir. Genç ve eğitimli insanların teknolojiye daha çabuk adapte oldukları görülmektedir.

Çalışmanın verileri genel olarak değerlendirildiğinde, her ne kadar insanların birçoğu mobil uygulamaları kullansa da bazı gruplar bu hizmetlerden yeterince faydalanamamaktadır. Bu nedenle dezavantajlı olan grupların tespit edilerek onlara uygun bir hizmet modeli geliştirmek faydalı olacaktır. Belki bu kişiler için özel uygulamalar dizayn edilebilir. Ayrıca teknoloji adaptasyonunun satın alma ve kullanma niyetini arttıran bir faktör olmadığı görülmüştür. Yeterli şekilde mobil uygulamaları kullanamayan kişiler de ileride bu hizmetlerden daha fazla faydalanmak istemektedir.

Eğlence faktörü kullanım niyetini arttırmaktadır. Günümüzde mobil uygulamaları iyi vakit geçirmek için kullanan kişiler gelecekte daha çok mobil hizmetlerden faydalanacaklardır. Eğlence kullanım niyeti üzerinde önemli bir etkiye sahiptir. Uygulamaları faydalı olarak görme ile eğlenme arasında da anlamlı bir ilişki bulunmuştur. Özellikle genç ve eğitimli kişilerin eğlence faktörüne önem verdiği düşünüldüğünde bu 
faktörün hizmet sağlayıcılar tarafından daha fazla önemsenmesi gerektiği ve insanları teknolojiye yaklaştırmak için daha çok kullanılması gerektiği söylenebilir.

Çalışmadan elde edilen veriler ışığında mobil uygulama üreticilerinin göz önüne alması gereken noktalar şöyledir;

- Mobil servis sağlayıcıları yapacakları uygulamayı hayata geçirmeden önce hedef kitlesini doğru saptamalıdır. Bazı grupların teknoloji kabulü zor olmaktadır. Bu nedenle karmaşık ve teknik bilgi gerektiren uygulamalar, her müşteri kesimi için uygun değildir.

- Mümkün olduğunca basit ve kullanışlı uygulamalar geliştirmek Algılanan Kullanım Kolaylığını sağlayacak bu ise tüketicilerin mobil hizmetleri daha faydalı görmelerine neden olacaktır.

- Offline uygulamaların indirilme sayısının, uygulamaların işlevini arttıracağı unutulmamalıdır.

- Eğlence faktörünü göz önüne almak gereklidir. Tüketicilerin önemli bir kısmı artık hayatını kolaylaştırmanın yanında eğlenmek için uygulamaları kullanmaktadır. Eğlence kullanım ve satın alma niyetini arttırmaktadır. Bu nedenle uygulama üreticilerinin eğitim, sağlık gibi uygulamalarda bile eğlence faktörünü göz önüne alarak içerik oluşturmalarında yarar vardır.

- İyi tasarlanmış uygulamalar kullanım zevkini arttırmakta bu da satın alma istekliliği doğurmaktadır.

- Mobil uygulama üretirken farklı ve yaratıcı olmak talebi arttıracaktır. Yenilikçi ve her işletim sistemine uygun geliştirilecek uygulamalar hizmet sağlayıcılara faydalı olabilir.

- Günlük hayatımızı kolaylaştıracak niş alanlar bulmak kullanım niyetini arttırabilir.

Daha önce yapılan çoğu çalışmada kullanım kolaylığının algılanan fayda üzerinde olumlu etkiye sahip olduğu görülmüştür. Bu anlamda çalışma literatürü destekler niteliktedir. Ancak birçok çalışmanın aksine bu çalışmada kullanım kolaylığının kullanım niyeti üzerine bir etkisi olmadığı görülmüştür. Çalışmanın özgün yanı eğlence faktörünü mobil hizmetlerde modele dahil etmesidir. Ayrıca Teknoloji Kabul Modeline eğlence faktörünü etkileyerek bunu mobil uygulamalara tüketici kabulü açısından ele alan araştıran ilk çalışmadır. Günümüzde teknolojinin çoğunlukla iyi vakit geçirmek için kullanıldığı düşünülürse bu faktörün Teknoloji Kabul Modellerinde yer alması gerekmektedir. Araştırmadan elde edilen verilere göre de modelin anlamlı olduğu ve eğlence değişkeninin kullanım niyetini etkilediği görülmüştür.

Her çalışmanın olduğu gibi bu çalışmanın da bazı kısıtları bulunmaktadır. Öncelikle teknoloji kabulü üzerine yapılan bu çalışma mobil uygulamalar üzerine gerçekleştirilmiştir. Modelin sınanması için farklı hizmet ve sektörlerde yapılacak çalışmalara ihtiyaç vardır. Ayrıca daha büyük bir örneklem üzerinde çalışma yapılabilir. Demografik faktörlerin temsili açısından daha dengeli bir dağılımın olması çalışmanın geçerliliğini arttıracaktır. Bunun yanında yalnızca yaş kuşakları üzerine bir çalışma da gerçekleştirilebilir. Böylece kuşaklara göre teknoloji kabulü daha iyi anlaşılabilir.

\section{KAYNAKÇA}

Aktaş, S. (2007). Teknoloji kabul modeli ile muhasebecilerin bilgi teknolojisi kullanımına yönelik bir uygulama. Gebze Yüksek Teknoloji Enstitüsü Sosyal Bilimler Enstitüsü. Yüksek Lisans Tezi. Gebze.

Abbas, H., Rouibah, K., Rouibah, S. (2011). Factors affecting camera mobile phone adoption before eshopping in the arab world. Technology in Society, (33), 271-283.

Ajzen, I. (1991). Theory of planned behavior, Organizational Behavior and Human Decision Processes, (50), 179211.

Ajzen, I., \& Fishbein, M. (1980). Understanding attitudes and predicting social behaviour, englewood cliffs, Prentice-Hall. Inc. New York.

Arı, E., Yılmaz, V., \& Başkan, E. (2015). Seçmen oy verme davranışlarının betimlenmesi için bir yapısal eşitlik model önerisi: yalova ili mahalli idareler seçimi örneği. Uluslararası Alanya İşletme Fakültesi Dergisi. 7(3), $1-17$. 
A. Uyar 11/1 (2019) 687-705

Bamba, F., \& Stuart, J, B. (2007). SMS Advertising, permission and the consumer: a study, Business Process Management Journal, 13(6), 815-829.

Bauer, H. H., Reichardt T., Barnes S. J., \& Neumann M. M. (2005). Driving consumer acceptance of mobile marketing: a theoretical framework and emprical study, Journal of Electronic Commerce Research. 6(3), 181-192.

Benbasat, I., \& Barki, H. (2007). Quo vadis, TAM? Journal Of The Association For Information Systems. 8 (4), 214.

Beyaznar, B. (2014). Mobil uygulamalarda insan kaynakları metrikleri tasarımı. T.C. Bahçeşehir Üniversitesi. Yüksek Lisans Tezi. Sosyal Bilimler Enstitüsü İnsan Kaynakları Yönetimi.

Cheong, J.H., \& Park, M. (2005). Mobile internet acceptance in korea, Internet Research, 15(2), 125-140.

Curran, J., \& Meuter, M. (2005). Self-Service Technology adoption: comparing three technologies, Journal of Services Marketing, 19(2), 103-113.

Çakır, A. (2014). Faktör Analizi, Yüksek Lisans Tezi, T.C. İstanbul Ticaret Üniversitesi Sosyal Bilimler Enstitüsü, İşletme Anabilim Dalı İşletme Doktora Programı. İstanbul.

Çetinsöz, C. B. (2015). Yerli turistlerin e-satın alma eğilimlerinin teknoloji kabul modelinde analizi. Elektronik Sosyal Bilimler Dergisi. 14(53), 242-258.

Çokluk, Ö., Şekercioğlu, G. ve Büyüköztürk Ş. (2014). Sosyal Bilimler İçin Çok Değişkenli İstatistik: SPSS ve LISREL Uygulamaları, 3. Baskı, Ankara: Pegem Akademi.

Dabholkar, P., \& Bagozzi, R. (2002). An attitudinal model of technology-based self-service: moderating effects of consumer traits and situational factors, Journal of the Academy of Marketing, 30(3), 184-201.

Davis, F. D. (1989). Perceived usefulness, perceived ease of use, and user acceptance of information technology, MIS Quarterly, 13(3), 319-340.

Davis, F. D., Bagozzi, R. P. \& Warshaw, P. R. (1989). User acceptance of computer technology: a comparison of two theoretical models, Management Science, 35(8), 982-1003.

Davis, F., Bagozzi, R., \& Warshaw, P. (1992). Extrinsic and intrinsic motivation to use computers in the workplace, Journal of Applied Social Psychology, 22(14), 1111-1132.

Doğan, M., Şen, R., ve Yılmaz V. (2015). İnternet Bankacılığına İlişkin Davranışların Planlanmış Davranış Teorisi ve Teknoloji Kabul Modeli Kullanılarak Önerilen Bir Yapısal Eşitlik Modeliyle İncelenmesi, Uşak Üniversitesi Sosyal Bilimler Dergisi, 8(2). 1-22.

Erdem, H. K. (2011). Kurumsal Kaynak Planlama Sistemlerinin Kullanımında Etkili Olan Faktörlerin Genişletilmiş Teknoloji Kabul Modeli İle İncelenmesi. Yüksek Lisans Tezi. İstanbul Teknik Üniversitesi Fen Bilimleri Enstitüsü, İstanbul.

Eriş, E.D., Timurcanday Ö.T., \& Süral, Ö.P. (2010). Bilişim teknolojilerinin kabulünde kişisel yenilikçilik, bilişim teknolojisi kaygısı ve özyeterlilik ile demografik değişkenlerin rolüne ilişkin yapısal modelleme. Çukurova Üniversitesi Bildiriler Kitabı, 773-777.

Erten, S. (2002). Planlanmış davranış teorisi ile uygulamalı öğretim metodu. Hacettepe Üniversitesi Edebiyat Fakültesi Dergisi, 19(2), 217-233

Fornel C., \& Larcker D. F. (1981). Evaluating structural equation models with unobservable variables and measurement error. Journal of Marketing Research, 18(1), 50.

Gong, W., \& Li, Z. G. (2008). Mobile youth in china: a cultural perspective and marketing implications, International Journal of Electronic Business. 6(3), 261-281.

Gögüş, G. Ç. (2014). Teknoloji kabul modeli ve değiştirme maliyetinin müşteri sadakati üzerine etkileri: muhasebe yazılım programları üzerine bir çalışma. Gebze Yüksek Teknoloji Enstitüsü Sosyal Bilimler Enstitüsü. Doktora Tezi. Gebze. 


\section{A. Uyar 11/1 (2019) 687-705}

Guritno, S., ve Siringoringo, H. (2013). Perceived usefulness, ease of use, and attitude towards online shopping usefulness towards online airlines ticket purchase, Procedia Social and Behavioral Sciences, (81), 212-216.

Gürbüz, S., ve Şahin, F. (2016). Sosyal Bilimlerde Araştırma Yöntemleri: Felsefe-Yöntem-Analiz. 3. Baskı, Ankara: Seçkin Yayıncılık.

Handan, Ç. (2012). Türkiye'deki üniversitelerde bulut bilişim teknolojisinin uygulanabilirliğinin teknoloji kabul modeli yaklaşımıyla belirlenmesi. Atatürk Üniversitesi Sosyal Bilimler Enstitüsü İşletme Anabilim Dalı. Doktora Tezi. Erzurum.

Hair, F. J., Anderson, E.R., Tatham, L.R., \& Black, C.W. (1998). Multivariate data analysis, Prentice Hall, New Jersey.

Hong, S.J., Thong, J. Y. L.,\& Tam, K. Y. (2006). Understanding continued information technology usage behavior: A comparison of three models in the context of mobile internet. Decision Support Systems, 42, 1819-1834.

Huang, T., Wu, F., Yu, J., \& Zhang, B. (2013). The Value Impact of Stock Liquidity: An International Evidence. Joreskog, K., \& Sörbom, D. (1996). Lisrel 8: User's Reference Guide. Scientific Software international, Chicago.

Kağıtçıbaşı, Ç. (2005). Yeni insan ve insanlar, Evrim Yayınları, İstanbul.

Kalyoncuoğlu, S. (2018). Tüketicilerin online alışverişlerindeki sanal kart kullanımlarının teknoloji kabul modeli ile incelenmesi, Afyon Kocatepe Üniversitesi Sosyal Bilimler Dergisi, 20(2), 193-213.

Kaya, S., \& Şenel, P. T. (2003). Zonguldak ilindeki bazı hastanelerde çalışan doktorların elektronik tıbbi kayıtlara hazırlık durumlarının değerlendirilmesi, http://ab.org.tr /ab05/ tammetin / 187.doc

Kim, M.J., Chung, N.,\& Lee, K.L. (2011). The effect of perceived trust on electronic commerce: shopping online for tourism products and services in south korea, Tourism Management, 32, 256-265.

Kim, J., \& Forsythe, S. (2009). Adoption of sensory enabling technology for online apparel shopping, European Journal of Marketing, 43(9/10), 1101-1120.

Lee, W.J., Kim T.U., \& Chung J.Y. (2002). User acceptance of the mobile internet, Proceedings of The First International Conference on Mobile Business, Athens.

Lee, Y., Kozar, K.A.,\& Larsen, K.R.T. (2003). The technology acceptance model: past, present, and future [teknoloji kabul modeli: geçmişi, bugünü ve yarını. Communications of The Association for Information Systems, 12(50), 752-780.

Lu, H. P., \& Yu-Jen Su, P. (2009). Factors affecting purchase intention on mobile shopping web sites. Internet Research, 19(4), 442-458.

Mardia, K. V. (1970). Measures of multivariate skewness and kurtosiswith applications. Biometrika, 57, 519530.

Mobilsiad Milli Uygulama Pazar Raporu (2013). Mobilsiad Milli Uygulama Pazarı Raporu 2013. Türkiye.http://www.mobilsiad.org.tr/img/ebulten/eb10/eb80_milli_uygulama_pazari_raporu.pdf

Moon, J.W., \& Kim, Y. G. (2001). Extending the tam for a world-wide-web context, Information \& Management, $38(4), 217-230$.

Namlı, Ç. (2010). Mobil uygulama kullanabilirliğinin değerlendirilmesi. İstanbul Teknik Üniversitesi, Fen Bilimleri Enstitüsü. Yüksek Lisan Tezi.

Niemelä-Nyrhinen J., \& Leskinen E (2014). Multicollinearity in marketing models: notes on the application of ridge trace estimation in structural equation modelling. The Electronic Journal of Business Research Methods,12(1), 3-15.

Nunkoo, R.,\& Ramkissoon, H. (2013). Travelers' e-purchase intent of tourism products and services, Journal of Hospitality Marketing \& Management, 22, 505-529. 
Özbek, V., Alnıaçık, Ü., Koç, F., Akkılık, M., E., Kaş, E. (2014). Kişilik özelliklerinin teknoloji kabulü üzerindeki doğrudan ve dolaylı etkileri: akıllı telefon teknolojileri üzerine bir araştırma. International Rewiev of Economics and Management. 2(1), 36-57.

Özdamar, K. (1999). SPSS ile Biyoistatistik (3. Baskl). Eskişehir: Kaan Kitabevi.

Özer, G., Özcan, M., \& Aktaş, S. (2010). Muhasebecilerin bilgi teknolojisi kullanımının teknoloji kabul modeli (TKM) ile incelenmesi. Journal of Yaşar University, 3278 - 3293.

Pagani, M. (2004). Determinants of adoption of third generation mobile multimedia services. Journal of Interactive Marketing, 18(3), 46-59.

Pavlou, P. (2003). Consumer acceptance of electronic commerce: integrating trust and risk with the technology acceptance model, International Journal of Electronic Commerce, 7(3), 101-134.

Pett, M. A., Lackey, N. R. ve Sullivan, J. J. (2003). Making Sense of Factor Analysis. London: Sage Publications.

Raykov, T., \& Marcoulides, G.A. (2006). A First Course in Structural Equation Modeling. Lawrence Erlbaum Associates, Inc. New Jersey.

Ryan, D. (2016). Dijital Pazarlama, Kültür Yayınları, İstanbul.

Scharl, A., Dickinger A., \& Murphy J. (2005). Diffusion and success factors of mobile marketing, Electronic Commerce Research and Applications, 159-173.

Schermelleh-Engel, K. \& Moosbrugger, H. (2003). Evaluating the fit of structural equation models: tests of significance and descriptive goodness-of-fit measures. Methods of Psychological Research Online, 8(2), 2374 .

Shankar, V. E., \& Malthouse, C. (2007). Moving Interactive Marketing forward, Journal of interactive Marketing, 20(1), 2-4.

Smith, R., Deitz, G., Royne, M. B., Hansen, J. D., Grünhagen, M., \& Witte, C. (2013). Cross-cultural examination of online shopping behavior: a comparison of norway, germany, and the united states. Journal of Business Research, 66, 328-335.

Smutkupt, P., Krairit, D., \& Esichaikul, V. (2010). Mobile marketing: implications for marketing strategies. International Journal of Mobile Marketing, 5(2).

Sultan, F., \& Rohm A. J. (2005). The coming era of 'brand in the hand' marketing, MIT Sloan Management Review, 47(1), 83-90.

Şıkla, E., Tunalı, D., \& Gülcan, B. (2015). Mobil internet kullanımının benimsenmesinde yakınsama faktörüyle teknoloji kabul modeli. Anadolu Üniversitesi Sosyal Bilimler Dergisi. 15(2).

Teo, S., Lim, V., \& Lai, R. (1999). Intrinsic and extrinsic motivation in internet usage, Omega The international Journal of Management Science, 27(1), 25-37.

Turan, B. (2011). Bilgi ve iletişim teknolojileri kullanımının teknoloji kabul modeli ile incelenmesi ve sınıf öğretmenleri üzerinde bir uygulama. Bilecik Üniversitesi Sosyal Bilimler Enstitüsü İşletme Anabilim Dalı. Yüksek Lisans Tezi. Bilecik.

Turan, B., ve Haşit, G. (2014). Teknoloji kabul modeli ve sınıf öğretmenleri üzerinde bir uygulama. Uluslararası Alanya İşletme Fakültesi Dergisi, 6(1), 109-119.

Turan, A. H. (2008). İnternet alışverişi tüketici davranışını belirleyen etmenler: geliştirilmiş teknoloji kabul modeli (e-tam) ile bir model önerisi. Akademik Bilişim, 723-731.

Turan, A. H., ve Özgen, F. B. (2009). Türkiye'de e-beyanname sisteminin benimsenmesi: geliştirilmiş teknoloji kabul modeli ile amprik bir çalışma. Doğuş Üniversitesi Dergisi, 10(1), 134-147.

Uğur, N. G., ve Turan, A. H. (2016). Mobil uygulama kabul modeli: bir ölçek geliştirme çalışması. Hacettepe Üniversitesi İktisadi ve İdari Bilimler Fakültesi Dergisi. 34(4), 97-125. 


\section{A. Uyar 11/1 (2019) 687-705}

Varnali, K., \& Toker, A. (2011). Mobile marketing research the-state-of-the-art. International Journal Of Information Management 30, 144-151.

Van der Heijden, H. (2003). Factors influencing the usage of websites: the case of a generic portal in the netherlands. Information \& Management, 40( 6), 541-549.

Venkatesh, V. \& Davis, F. (2000). A theoretical extension of the technology acceptance model: four longitudinal field studies, Management Science, 46( 2), 186-204.

Yazıcıŏ̆lu, Y. ve Erdoğan, S. (2004). SPSS Uygulamalı Bilimsel Araştırma Yöntemleri. Ankara: Detay Yayıncilık.

Yılmaz, V. ve Doğan, M. (2016). Planlanmış Davranış Teorisi Kullanılarak Önerilen Bir Yapısal Eşitlik Modeli ile Geri Dönüşüm Davranışlarının Araştıılması. Anadolu Üniversitesi Sosyal Bilimler Dergisi. 2016 Kasım Özel Sayısı, 191-205.

Wu, J. H., \& Wang, S. C. (2005). What drives mobile commerce? An empirical evaluation of the revised technology acceptance model. Information \& Management, 42(5), 719-729.

Zengin, A. S., ve Özkil, C. (2017). Teknolojinin kabulü ve kullanımı faktörlerinin tüketicilerin mobil reklam kullanma niyetleri üzerindeki etkisi. İsletme Araştırmaları Dergisi, 9(4), 551-570.

http://www.americandialect.org (2011). "App" voted 2010 word of the year by the American Dialect Society. http://www.americandialect.org/app-voted-2010-word-of-the-year-by-theamerican-dialect societyupdated (Erişim Tarihi: 18.4.2018).

http://www.haberturk.com (2018). Türkiye'de Akıllı Telefon Kullanım Oranları http://www.haberturk.com/turkiye-de-akilli-telefon-kullanim-orani-nedir-1793115-ekonomi (Erişim Tarihi: 4.4.2018).

http://www.iticu.edu.tr (Erişim Tarihi: 15.4.2018).

https://www.webrazzi.com (2016). Türkiye'de mobil kullanıcı araştırmasının sonuçlarını yayımlıyoruz. https://webrazzi.com /2016/05/11/turkiyede-mobil-kullanici-arastirmasinin-sonuclarini-yayimliyoruzozel-haber/ (Erișim Tarihi: 18.3.2018).

https://www.webrazzi.com (2017). Mobil uygulama gelirleri 17 milyar dolara, indirilme sayıları 26 milyara yükseldi. $\quad$ https://webrazzi.com/2017/10/24/kuresel-mobil-uygulama-gelirleri-ve-indirmeleri-rekorkirdi/ (Erișim Tarihi: 5.4.2018).

http://www.tdk.gov.tr. (Erişim Tarihi: 2.4.2018). 